\title{
Design of a small-scale UAV textile wing fluid-structure numerical modelling DOI: 10.35530/IT.072.04.1844
}

\author{
ADRIAN SALISTEAN \\ DOINA TOMA
}

IONELA BADEA

MIHAELA JOMIR

\section{ABSTRACT - REZUMAT \\ Design of a small-scale UAV textile wing fluid-structure numerical modelling}

This paper depicts the early phase in the research development for an integrated UAV (Unmanned Aerial Vehicle) support system tailored for emergency response actions and remote sensing. The support system is envisioned as an integrated Unmanned Aerial System (UAS) system that consists of one or more ultralight multifunctional aerial units with a configuration that can be adapted to the nature of the intervention: monitoring, mapping, observation, logistics etc. These aerial units comprise of para-motor type UAVs that use textile paraglider wings of a special design.

The overall development and theoretical design aspects that are involved in this research is subject of change been part of an ongoing research study. Starting from wing airfoil and material selection, a design phase is under development for a single sail paraglider wing that can meet the operational demands for the envisioned system. The wing is designed mainly to have an easy handling, predictable deployment at all times and good aerodynamic characteristics. The paper tackles in particular the stretch effect on the wing and the influence on these aerodynamic characteristics as well as means of minimizing the adverse effects.

Keywords: Unmanned Aerial System (UAS), parachute, paraglider, SingleSkin sail, technical textiles

\section{Proiectarea unui UAV la scară redusă cu aripă textilă, modelare numerică a interacțiunii fluid-structură}

Această lucrare descrie faza incipientă a dezvoltării unui sistem integrat UAV pentru suport adaptat acțiunilor de răspuns în caz de urgență și teledetecție. Sistemul de asistență este conceput ca un sistem integrat aerian fără pilot (UAS), care constă din una sau mai multe unități aeriene ultraușoare multifuncționale cu o configurație, care poate fi adaptată la natura intervenției: monitorizare, cartografiere, observare, logistică etc. Aceste unități aeriene sunt UAV-uri de tip para-motor, care utilizează aripi textile de tip parapantă cu un design special.

Aspectele generale de dezvoltare și de proiectare teoretică, care sunt implicate în această cercetare sunt în curs de dezvoltare, făcând parte dintr-un studiu de cercetare în desfășurare. Începând de la selecția materialelor și a aripilor aerodinamice, este în curs de dezvoltare o fază de proiectare pentru o aripă textilă de tip parapantă, care poate satisface cerințele operaționale pentru sistemul prevăzut. Aripa este proiectată în principal pentru a avea o manevrabilitate ușoară, o desfășurare previzibilă în orice moment și caracteristici aerodinamice ridicate. Lucrarea de față abordează în special efectul de întindere asupra aripii și influența asupra acestor caracteristici aerodinamice, precum și mijloacele de minimizare a efectelor adverse.

Cuvinte-cheie: Sistem Aerian Fără Pilot (SAFP), parașută, parapantă, aripă SingleSkin, textile tehnice

\section{INTRODUCTION}

In the current industrial context, information technology contributes preponderantly to the development of applications through rapid design and prototyping, digital and virtual production, modelling and simulation.

The design of most modern ram-air wings involves a large number of prototypes (sometimes more than 15 is possible) The reason is that the shape of the real wing is so much different from what is designed in the computer that many real life tests are needed to trim and fine-tune the wing to get the desired flight characteristics [1-3].

The accepted method to design and build ram-air wings is to make a design in the computer that is based on a previous model. This design is built and test flown. It is trimmed and tuned to improve its characteristics. These changes are incorporated in the next prototype, which is also trimmed and tuned to further improve the flight characteristics. And so on until the design is good enough to put it on the market [4].

The difference between the computer model and the real wing comes from the fact that accurate calculation and simulation of the deformation of a ram-air wing is very difficult and requires a large amount of computing power. Ideally, a ram-air wing would be designed by means of fluid-structure interaction (FSI). This is a combination of finite-element analysis (FEA) of the fabric wing and computational fluid dynamics (CFD) analysis of the flow around and inside the wing.

In this article, we will analyse the effect of fabric stretching in the aerodynamic shape of the wing for a UAV support system tailored for emergency response actions and remote sensing [5]. Basically it's a scaled down paraglider wing of about $6 \mathrm{~m}$ span. 


\section{MATERIALS AND METHODS}

The creation of a prototype starts with pre-dimensioning, everything is done with a software program developed within the institute, which includes a SQL database (figure 1, $a$ and $b$ ) that can easily be edited and stores the characteristics of the materials commonly used in making parachutes. This database is populated with the existing stock of materials from which to select the parachute fabric. Material selection can be done manually or automatically by the program based on the physical parameters of the required material obtained from the calculation and/or on the basis of the existing stock.

The implementation methods in software for the initial pre-dimensioning phase derive from the empirical and interpolation graphical methods currently used for parachute design, then on the virtual model additional computational checks are iterated using the finite element methods, on the behaviour of the parachute from deployment, flight attitude and landing.

Using the data obtained with the pre-dimensioning program, the drawing of the three-dimensional model (figure $1, c$ ) is automatically made as input in the 3D modelling script. After generating the $3 \mathrm{D}$ model, it undergoes the simulation and structural phase check for all phases of the flight, starting with the launch, stabilized flight or turbulent atmosphere and then landing. Estimation of the maximum loads in the canopy is done at launch, because at this moment the forces acting on the constructive elements of the parachute can exceed tens of times the forces in the stabilized flight, depending on the velocity and the launching altitude. For paragliders this is no longer valid, for this is set the launching altitude at $0 \mathrm{~m}$ and the speed at $20 \mathrm{~km} / \mathrm{h}$, in this particular case in order to obtain the maximum forces simulation is made at the maximum speed of a paraglider, namely on a slope flight of $80 \mathrm{~km} / \mathrm{h}$. In this phase of the design we can estimate how fabric stretching generally affects the aerodynamics of a wing. A case was implemented in software for NACAxx12 wing profiles using as a template model of the NACA0012 airfoil for which we had prior experimental measurement data.

After the simulation, changes to the dimensional parameters can be adjusted slightly if so desired. The $3 \mathrm{D}$ model is then discretized automatically in its component parts and broke down into the patterns. After this, the necessary markings are made on the width of the fabric (figure 1,d) for cutting the parts.

Embodiments of the parts are sent to the cutting machine which performs the automatic cutting (figure $1, e)$ of the parts. They are then picked up by an operator, marked and then stitched, usually with two needle seams.

\section{RESULTS AND DISCUSSION}

When a ram-air wing is inflated the ribs will give the wing its aerodynamic shape [6]. The space in between the ribs will billow out due to the internal overpressure (stagnation pressure) in the wing. At the cell centres the wing won't have the shape that was intended by the designer. Looking in span-wise

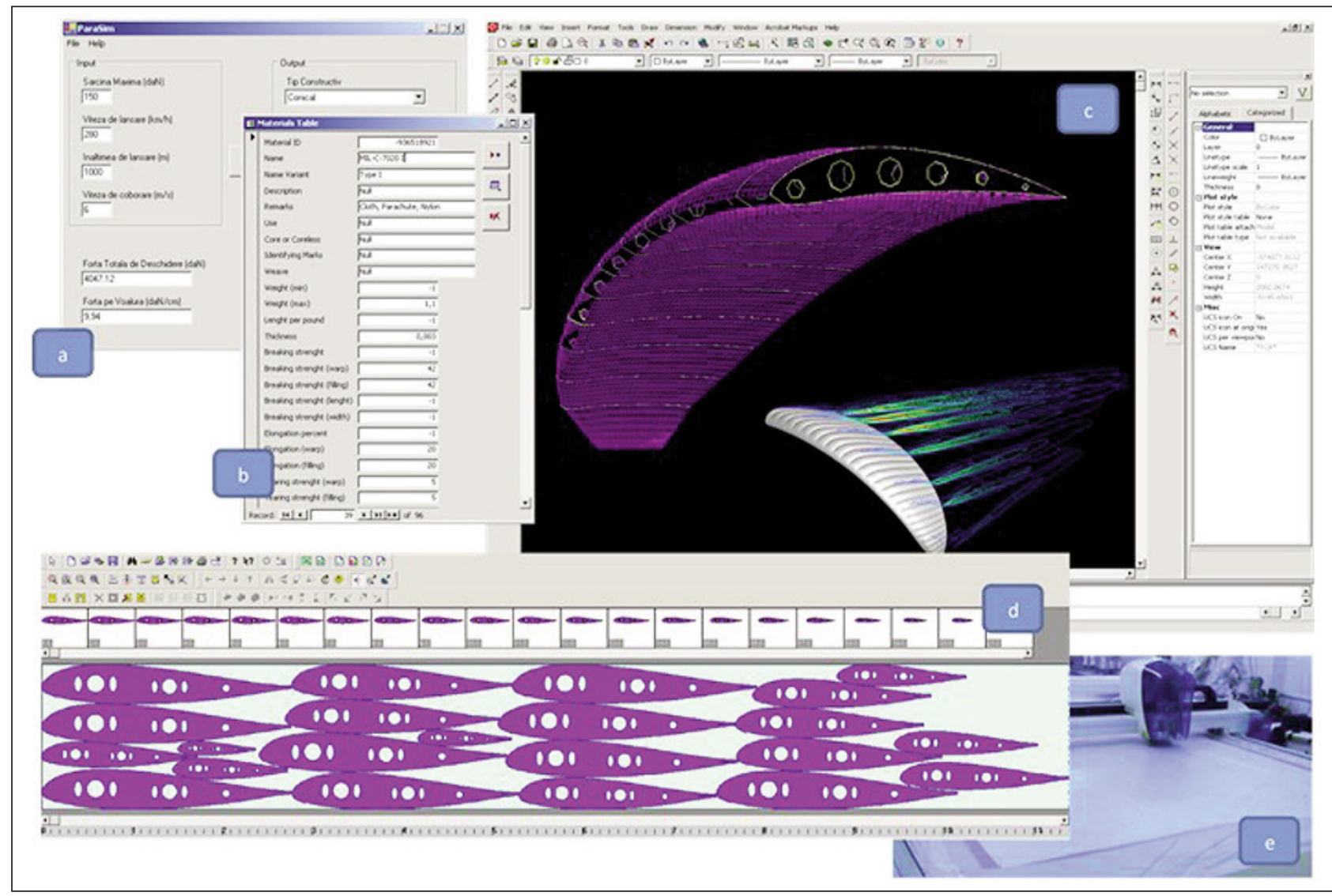

Fig. 1. Textile wing design and manufacture workflow 
direction the wing has bumps at the cell centres and grooves at the ribs.

Computational Fluid Dynamics (CFD) is a method of solving the governing equations of fluid and gas flow, the Navier-Stokes equations, in a finite number of discrete volumes.

The first step in CFD is to create a volume around the wing geometry in which the fluid calculations are performed. This volume is discretized into small volumes that, in this case, have the shape of tetrahedra and prisms. This is the grid or mesh. An unstructured grid with prisms and tetrahedra is used because this allows easy and quick grid generation with good control over the grid density. Especially later when the whole wing will be analysed with CFD the flexibility of an unstructured grid may be advantageous compared to a structured grid.

For turbulence modelling the k-omega SST model is used with transitional flow and enhanced wall treatment.

Enhanced wall treatment is used instead of wall function, because it is anticipated that there is premature flow separation on the stretched wing. Wall functions predict separation far worse than enhanced wall treatment. Also, using enhanced wall treatment the grid resolution is much higher in the boundary layer. This allows a more detailed analysis of the flow. The price is more cells and more computation time.

Wrinkles that normally occur in the fabric are not modelled. To model the small wrinkles an enormous amount of cells would be required to capture their shape accurately. Another option would be to model the wrinkles with a certain surface roughness. Using sand grain roughness requires the wall functions boundary layer treatment.

Figure 2 illustrates the influence of the free stream turbulence intensity and length scale. The difference is in the different shades of blue in between the inlet on the left side and the leading edge of the airfoil. The colour scale represents the turbulence intensity.

The computational model is constructed from the predimensioned layout of canopy fabric panels and suspension lines (they are assumed rigid and its aerodynamics is obtained from empirical data). This is the un-deformed configuration used to start the simulation.

The simulations used in the background are conducted using version 971 of the LS-Dyna solver.

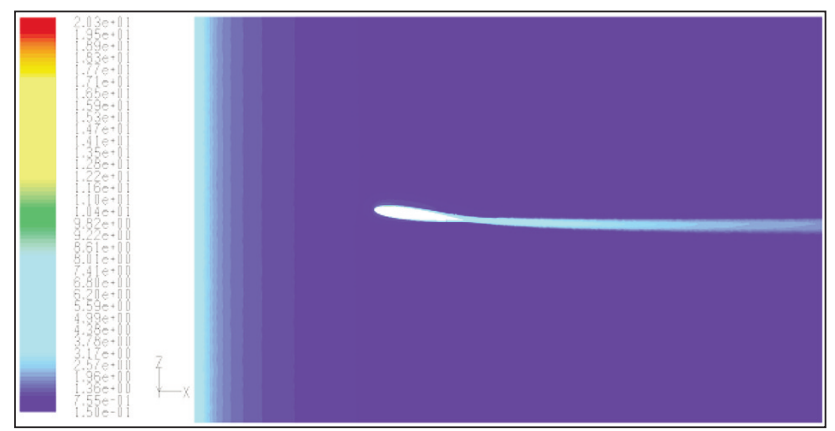

Fig. 2. 10\% turbulence intensity, $0.5 \mathrm{~mm}$ turbulence length scale

\section{Structural modelling}

The structural solution uses a large-displacement small-strain FE formulation with explicit time integration. This approach is quite accurate (only small tensile strains are expected) and allows an efficient coding. The solver models membranes, cables and solid bodies using linear elements. Since cables and membranes lack bending stiffness and buckle under compressive loads, a wrinkling model is used to correct the elemental stresses. Structural components with negligible deformation can be modelled as rigid bodies. This greatly reduces the computational cost with no effect on the structure dynamics.

The time integration is performed with an explicit second-order scheme, which despite the inherent time increment limitations, provides a robust and fast solution for highly non-linear problems.

Note that the complete dynamics of the deformable parachute payload system subject to inertial, aerodynamic and gravity forces is obtained because the trajectories of all the grid points are integrated in time. Some guidelines for tuning these parameters are given in [7].

\section{Aerodynamic modelling}

Potential flow aerodynamics was considered costeffective in this work because no extensive detached flow is expected under nominal operation of gliding parachutes. Hence, the flow solution is obtained with an unsteady panel method using low-order doublets and sources. The constant strength panels lower the complexity and computational cost, while the addition of sources improves the accuracy compared to a doublet-only method $[8,9]$.

\section{FSI Coupling procedure}

A 2-way staggered scheme is used to couple the aerodynamic and structural solvers, with one fluid solve and one structure solve per time step. Since the mesh is the same, no interpolation of results is required during the simulation. This allows obtaining both the transient and steady-state response of the structure in a very efficient way. In typical calculations, the stability limit of the structural solver is small; therefore several structural time increments are performed per aerodynamic step. Although this could affect the high-frequency response, it is not a serious limitation because these modes usually have low amplitude, and affect only small parts of the structure. The mechanical properties of the materials used for the canopy (figure 3) and suspension lines are those of the real textile materials obtained from the material database of the program.

In order to obtain the steady descent characteristics of the parachute system, the simulations are started with the un-deformed model and continue until the equilibrium flight configuration is reached. The model is released with an initial velocity. Due to the unsteadiness of the problem, the steady flight condition is determined in an approximated manner (total system acceleration below a given threshold). 


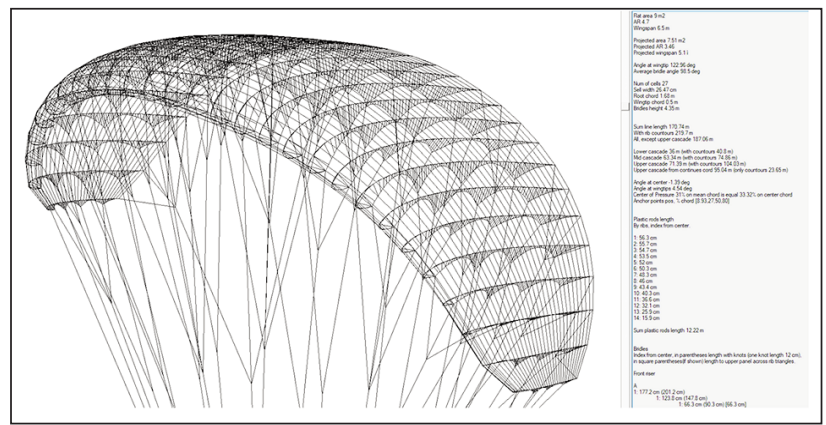

Fig. 3. 3D model of the UAV canopy

First, the influence of side slip on lift and drag is analysed. Figure 4 shows the polar of lift coefficient versus angle of attack for slip angles of 0,10 and 20 degrees of the normal NACA0012 profile without stretching. For reference additional curves are shown: X-foil low turbulence, X-foil high turbulence (3\%), data from Abbot [10] and data form McCroskey [11]. The first thing to notice is the spread of the data. Clearly the different sources give different outcomes. The NACA0012 profile is very sensitive to Reynolds number and free stream turbulence.

The difference between the fluent simulation and X-foil is likely to come from the various differences of the numerical models. First of all X-foil is a 2D simulation. In Fluent a quasi 3D simulation was used. That means that a slice of wing was simulated between two symmetry planes. The consequence is that also out of plane turbulence affects the flow. Furthermore, the way in which a turbulent boundary layer is treated is different. X-foil calculates with a transition point on the upper and lower surface. The Fluent flow is fully turbulent and is initialized with certain free stream turbulence. The maximum lift coefficients of the two approaches differ by $6.5 \%$.

In figure 5 the lift coefficients of the normal NACA0012 profile and the quasi 2D stretched NACA0012 wing are compared. The trends in this figure are that stretching decreases the lift slope in all cases. In the cases of side slip the stall point is postponed and stall is more gradual.

Further on, the model was split into two configurations $\mathrm{M} 1$ for a classic closed cell wing and the second M2 for a single skin type paraglider wing. The intention was to observe the actual rib deformation in both

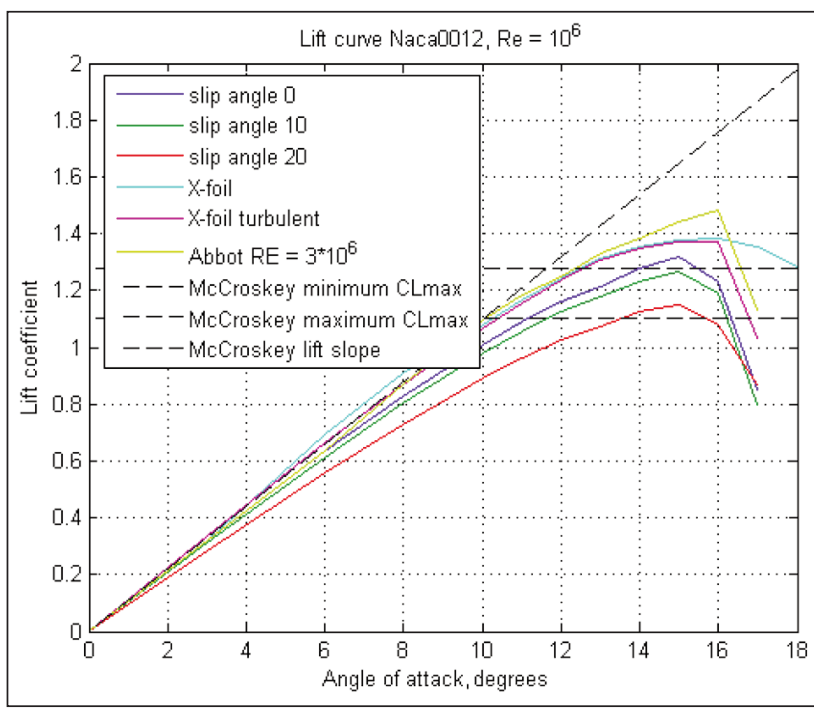

Fig. 4. Lift coefficients of the NACA0012 profile (not stretched) for 0,10 and 20 degrees slip angle. All reference data are at 0 degrees slip angle

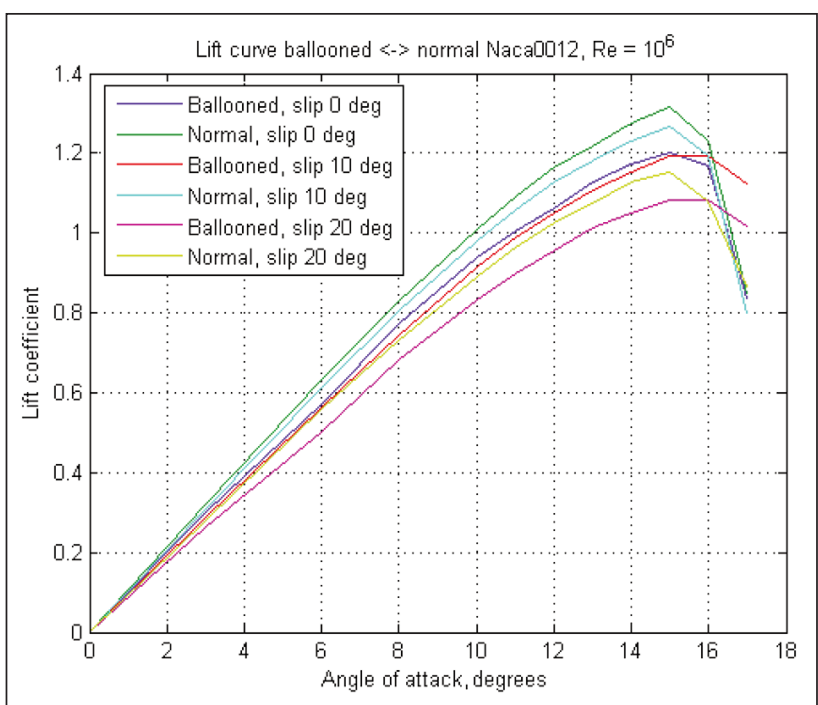

Fig. 5. $C_{L}$ comparison of the normal and stretched NACA0012 wing

of these wing types to better choose the output model, shown in figure 6 .

Based on these models the single skin rib deformation was smaller but overall flight characteristics were worse in every department. However the single skin construction is simpler and gives more predictable

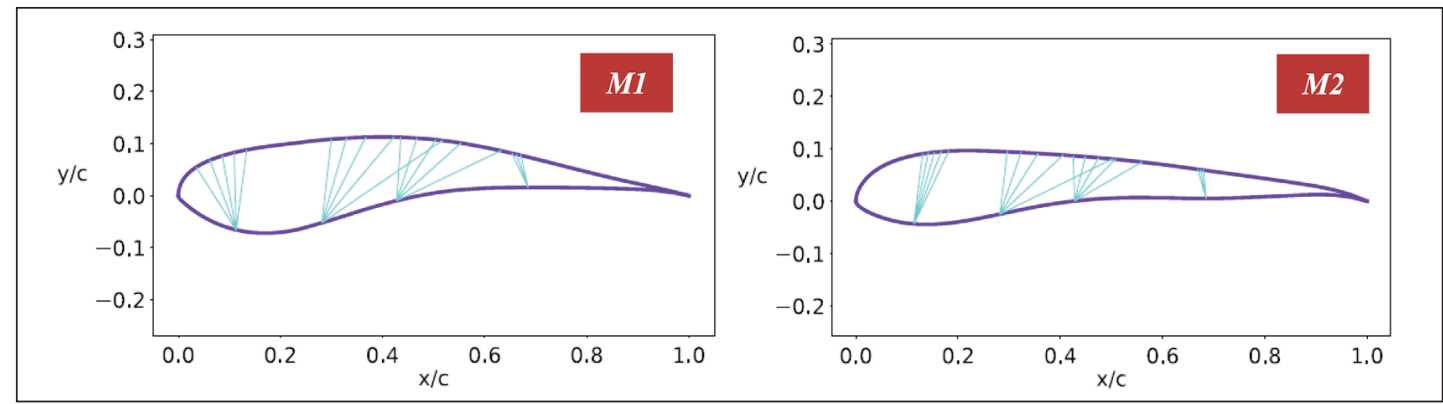

Fig. 6. Dynamic deformation of the ribs in the case of the two aerodynamic models M1 (classic cell wing) and M2 (single skin wing) 
results on small scale wings at low Reynolds numbers than a classic pressurized cell wing.

\section{CONCLUSIONS}

From the CFD analysis of the normal and stretched NACA0012 wing it can be concluded that fabric stretching has the following influence on the wing:

- reduced maximum lift coefficient;

- reduced lift slope;

- reduced lift-to-drag ratio;

- increased drag at a given lift coefficient;

- increased flow separation at the trailing edge;

- increased turbulence production and energy dissipation in the grooves;
- when air flows at a certain side slip angle over the wing, fabric stretch causes more gradual stall behaviour;

- rib deformation on single skin wings is lower than in that of classic pressurized cell wing.

In truth the error of these values is quite small but when the wing is also small any small deformations translate to large flight characteristics variations. Thus corrections in fabric patterns can be made prior to the next manufacturing phase in order to minimize these adverse effects in the final product.

\section{ACKNOWLEDGEMENTS}

This study was performed with support of the NUCLEU project PN19170201 - SiMaLogPro; Grant agreement number 4N/08.02.2019.

\section{REFERENCES}

[1] Bartkowski, P., Zalewski, R., Passive safety system for small unmanned aerial vehicles, In: XXII Slovak-Polish Scientific Conference on Machine Modelling and Simulations 2017 (MMS 2017), Book Series MATEC Web of Conferences, 2018, 157, 03001, https://doi.org/10.1051/matecconf/201815703001

[2] Niculescu, C., Salistean, A., Butoescu, V., Olaru, S., Equipment for paraglider - the emergency parachute, In: Industria Textila, 2010, 61, 1, 11-16

[3] Olaru, S., Salistean, A., Niculescu, C., Matenciuc, C.-C., Teodorescu, M., Optimization models of parachute manufacture process, Industria Textila, 2010, 61, 3, 124-128

[4] Zhong, Y.C., Suraj, R., Wang, C., Chia, E.S.M., Joshi, S.C., Chen, Z., Damage advancement behavior in braided composite structures for mini aerial vehicles, In: Mechanics of Advanced Materials and Structures, 2018, 25, 11, 889-900, https://doi.org/10.1080/15376494.2017.1310335

[5] Green, L.V., Kolesar, P.J., Improving emergency responsiveness with management science, In: Manage. Sci., 2004, 50, 8, 1001-1014, 173-187

[6] Knache, T.W., Parachute Recovery Systems - Design Manual, Para Publishing, Santa Barbara, California, 1992, 287-288

[7] Flores, R., Ortega, E., Onate, E., Simple and efficient numerical tools for the analysis of parachutes, In: Engineering Computations, 2014, 31, 5

[8] Ashby, D.L., Potential flow theory and operation guide for the panel code PMARC_14, NASA TM-1999-209582, 1999

[9] Mihai, C., Ene, A., Jipa, C., Ghimus, C.D., Zamfirache, O.D., Nite, C., Testing of the ammunition stabilizationdeceleration system structure in static conditions and in the subsonic aerodynamic tunnel, In: Industria Textila, 2019, 70, 2, 160-164, http://doi.org/10.35530/IT.070.02.1649

[10] Abbott, I.H., Von Doenhoff, A.E., Theory of Wing Sections, Dover Publishing, New York, 1959

[11] McCroskey, W.J., A Critical Assessment of Wind Tunnel Results for the NACA 0012 Airfoil, U.S. Army Aviation Research and Technology Activity, Nasa Technical Memorandum, 1987

\section{Authors:}

\section{ADRIAN SALISTEAN, DOINA TOMA, IONELA BADEA, MIHAELA JOMIR}

National Research and Development Institute for Textiles and Leather, 16 Lucretiu Patrascanu Street, 030508, Bucharest, Romania e-mail: office@incdtp.ro

\section{Corresponding author:}

ADRIAN SALISTEAN

e-mail: adrian.salistean@incdtp.ro 